\title{
Role of MSX1 Gene Mutation as Predictive Factor in Cleft Palate/Lip-A Mini Review on Facial Skeletal Malformations
}

\author{
Janaki CS ${ }^{1}$ and Lokanadham $\mathbf{S}^{2 *}$ \\ ${ }^{1}$ Department of Anatomy, Asan Memorial Dental College and Hospital, Chengalpet, Tamilnadu, India \\ ${ }^{2}$ Department of Anatomy, Government Medical College, Palakkad, Kerala, India
}

\section{Introduction}

Syndromic cases of cleft lip/palate are associated with genes like MSX1 and PAX9 in formation of cleft lip/palate discussed in previous studies [1]. In knockout humans and mice, the phenotypic abnormalities are manifested due to MSX gene mediated inductive interactions. MSX1, IRF6 PVRL1, and TBX22 causes syndromic oral clefts as a single gene defect have been identified $[2,3]$. These are good candidate genes for some instances of nonsyndromic Cleft lip/palate and CPO because it has been shown that reduced activity of the proteins they encode can affect oral development [4,5]. MSX1 is a homeobox gene under non-clustered category plays significant role in clefting in humans. Five variants of MSX1 mutation were found as responsible for cleft palate forming. They were: A34G, G110G, P147Q, M37L and G267A. The MSX1 gene critical for the normal development of the teeth and other structures in the mouth. MSX1 and MSX2 expressed with Bmp4 in mesenchymal cells that condense around tooth buds. Patterning of incisors, canine sand premolars and craniofacial development. The mutations within MSX1 may also lead to rare congenital defects such as Wiktop syndrome and Wolf-Hirschhorn syndrome [6,7]. Studies in knockout mice and humans indicate that defects in the genes MSX1 and PAX9 are possible causes of Non-syndromic cleft lip/palate associated with hypodontia [8]. Studies on animal research related to cellular and molecular morphogenesis of face are involved in genetic complexities in variant genes like MSX1 SHH, FGF10, SHOX2 and BMP4 were stated in the previous studies [8-10].

\section{Role of MSX1 Gene Mutation in Formation of Cleft Lip/ Palate}

MSX1 and MSX2 are the members of MSX gene family and are strongly expressed in the mesenchyme of the developing facial component derived from neural crest cells and plays major role in specification of face and skull development [10]. The regulation, expression and functional analysis of MSX genes have major predictive relevance to craniofacial development in humans and mice. MSX1 plays major role in formation of secondary lip/palate indicating mutations of MSX1 gene significantly enhancing the isolated cleft palate/lip. $2 \%$ of non-syndromic clefts in humans are due to mutations in MSX1 gene. The interaction between genes showed influence on formation of cleft palate is higher indicating significant role in $20 \%$ cleft palate/lip cases [11]. MSX1 gene contribution in formation of cleft palate, isolated tooth agenesis and tooth agenesis was reported in previous studies [12,13]. Mutations of MSX1 gene and its rare variants stated in individuals with hereditary tooth agenesis and cleft lip/palate [14-16]. Previous literature stated that secondary palatal cleft and developmental failure of tooth noted in a mouse due to lack of MSX1 gene [17]. Children are more affected with cleft palate associated with tooth agenesis when compared with normal population $[18,19]$. Severity of cleft palate/lip markedly increased with hypodontia and is more significant in children. It has been proposed that mutations of MSX1 gene alone could contribute to as many as $2 \%$ of total cleft lip and palate $[5,20]$. The mutation of MSX1 P147Q was first reported in a Vietnamese population and this mutation was thought to have arisen from a founder individual
Vietnamese families. The mutation was later found in two Filipino families. The frequency of the MSX1 P147Q mutation was as high as $8 \%$ in Thai people in a study suggested that MSX1 P147Q mutation is not pathogenic [20]. Perhaps the most interesting case related to the MSX1 P147 Q saga is that of one Vietnamese child who was born with a sporadic cleft lip and palate carried two MSX1. Mutation of MSX1 is associated with hypodontia and cleft palate/lip. Cleft lip/palate and tooth agenesis was observed due to a nonsense mutation in exon 1 of MSX1 gene in chromosome $4 \mathrm{p}$ in a Dutch family [2]. The mouse homeobox gene $M S X 1$ is expressed only in the anterior palatal mesenchymal cells and the loss of MSX1 function in mice results in a complete cleft palate rather than only an anterior cleft, indicating the importance of anterior palate development in palate fusion [17,21,22]. Furthermore, the cleft palate caused by MSX1 inactivation can be rescued by transexpression of the BMP4 gene $[21,22]$. Interestingly, in vitro explant culture showed that only the anterior, but not the posterior, palatal mesenchymal cells can proliferate in response to the addition of BMP $[21,22]$. The expression of PAX9 is restricted to the posterior region during palate development and disruption of this gene in mice results in cleft palate $[22,23]$. Statistical evidence of gene interaction leading to clefts has been reported for MSX1 (a transcription repressor) and TGF $\beta 3$ (involved in cell differentiation) and for MSX1 and RGFA (a growth factors) $[13,24]$. In both studies the evidence of interaction was related to carrying two copies of the MSX1 risk allele. Cleft lip/palate and tooth agenesis outside the cleft region cases were associated with the variants of MSX1gene [12].

\section{Future perspectives and Conclusion}

The genetic factor is thought to play a crucial role in $20 \%$ of cases of clefts. The MSX1 and TGF $\beta 3$ genes are found to be the genes most strongly related to cleft anomalies. The expression of an antisense RNA which is partial complimentary to the protein coding sense RNA due to bidirectional transcription plays significant role in regulation of MSX1gene expression in developmental sites [25]. Antisense RNA has been associated with various processes, such as RNA interference, imprinting and transcription inhibition. In contrast, hypomorphic MSX 1 allele has ability to reduce the activity of antisense RNA to inhibit its function as a transcriptional suppressor. Another hypomorphic allele in a different gene TGFA or TGFB3 could decrease the ability of those

*Corresponding author: Dr. Sadhu Lokanadham, Assistant Professor, Department of Anatomy, Government Medical College, Palakkad, Kerala-678013, India, Tel: +919573066311; E-mail: loka.anatomy@yahoo.com

Received December 03, 2017; Accepted December 27, 2017; Published December 29,2017

Citation: Janaki CS, Lokanadham S (2017) Role of MSX1 Gene Mutation as Predictive Factor in Cleft Palate/Lip-A Mini Review on Facial Skeletal Malformations. J Mol Genet Med 11: 309 doi:10.4172/1747-0862.1000309

Copyright: (c) 2017 Janaki CS, et al. This is an open-access article distributed under the terms of the Creative Commons Attribution License, which permits unrestricted use, distribution, and reproduction in any medium, provided the original author and source are credited 
genes to promote growth or cell differentiation. Alone, the hypomorphic allele does not lead to disease, even if two copies of the same are present. However, if hypomorphic allele in more than one gene occur in the same individual, the reduced MSX1 function (by the individual carrying two copies of the hypomorphic alleles) combined with the reduced TGF A (or TGFB3) may lead to cleft lip and palate. Recent studies suggest that MSX1 causative mutations for tooth agenesis may not be sufficient to cause oral clefts. Few researchers stating in contrast with MSX1 gene as predictive factor influencing clefts and also claim that MSX1 might not be an etiologic factor responsible for orofacial clefting. To conclude; MSX1 and other associated genes plays predictive role in formation of cleft palate/lip when it occurs in parallel with the PAX9 gene mutation. The diagnostic techniques in the field of molecular genetics make it possible to identify relevant morphogenesis or genetic markers in facial malformations due to MSX gene family to be evaluated in clear due to its clinical importance.

\section{References}

1. Cox TC (2004) Taking it to the max: The genetic and developmenta mechanisms coordinating midfacial morphogenesis and dysmorphology. Clin Genet 65: 163-176.

2. Van den Boogaard MJ, Dorland M, Beemer FA, Van Amstel HK (2000) MSX1 mutation is associated with orofacial clefting and tooth agenesis in humans. Nat Genet 24: 342-343.

3. Suzuki Y, Jezewski PA, Machida J, Watanabe Y, Shi M, et al. (2004) In a Vietnamese population, MSX1 variants contribute to cleft lip and palate. Genet Med 6: 117-125

4. Lidral AC, Murray JC, Buetow KH, Basart AM, Schearer H, et al. (1997) Studies of the candidates genes TGFB2, MSX1, TGFA, and TGFB3 in the etiology of cleft lip and palate in the Philippines. Cleft Palate Craniofac J 34: 1-6.

5. Jezewski PA, Vieira AR, Nishimura C, Ludwig B, Johnson M, et al. (2003) Complete sequencing shows a role for MSX1 in non-syndromic cleft lip and palate. J Med Genet 40: 399-407.

6. Robert B, Sassoon D, Jacq B, Gehring W, Buckingham M (1989) Hox-7, a mouse homeobox gene with a novel pattern of expression during embryogenesis. EMBO J 8: 91-100.

7. Beaty TH, Wang H, Hetmanski JB, Zeiger JS, Liang KY, et al. (2001) A casecontrol study of nonsyndromic oral clefts in Maryland. Ann Epidemiol 11: 434442.

8. Moreno LM, Arcos-Burgos M, Marazita ML, Krahn K, Maher BS, et al. (2004) Genetic analysis of candidate loci in non-syndromic cleft lip families from Antioquia-Colombia and Ohio. Am J Med Genet A 125: 135-144.

9. Fallin MD, Hetmanski JB, Park J, Scott AF, Ingersoll R, et al. (2003) Family- based analysis of MSX1 haplotypes for association with oral clefts. Genet Epidemiol 25: 168-175.

10. Ferguson MWJ (2000) A hole in the head. Nat Genet 24: 330-331.

11. Kohli SS, Kohli VS (2012) A comprehensive review of the genetic basis of cleft lip and palate. J Oral Maxillofac Pathol 16: 64-72.

12. Schultz RE, Cooper ME, Daack-Hirsch S, Shi M, Nepomucena B, et al. (2004) Targeted scan of fifteen regions for nonsyndromic cleft lip and palate in Filipino families. Am J Med Genet A 125: 17-22.

13. Slayton RL, Williams L, Murray JC, Wheeler JJ, Lidral AC, et al. (2003) Genetic association studies of cleft lip and/or palate with hypodontia outside the cleft region. Cleft Palate-Craniofac J 40: 274-279.

14. Vieira AR, Orioli IM, Castilla EE, Cooper ME, Marazita ML, et al. (2003) MSX and TGFB3 contribute to clefting in South America. J Dent Res 82: 289-292.

15. Vastardis H, Karimbux N, Guthua SW, Seidman JG, Seidman CE (1996) A human MSX1 homeodomain missense mutation causes selective tooth agenesis. Nat Genet 13: 417-421.

16. Jumlongras D, Bei M, Stimson JM, Wang WF, De-Palma SR, et al. (2001) A nonsense mutation in MSX1 causes Witkop syndrome. Am J Hum Genet 69: $67-74$.

17. De Muynck S, Schollen E, Matthijs G, Verdonck A, Devriendt K, et al. (2004) A novel MSX1 mutation in hypodontia. Am J Med Gesnet A 128: 401-403.

18. Satokata I, Maas R (1994) MSX1 deficient mice exhibit cleft palate and abnormalities of craniofacial and tooth development. Nat Genet 6: 348-356.

19. Ranta R (1986) A review of tooth formation in children with cleft lip/palate. Am J Orthod Dentofacial Orthop 90: 11-18.

20. Shapira Y, Lubit E, Kuftinec MM (1999) Congenitally missing second premolars in cleft lip and cleft palate children. Am J Orthod Dentofacial Orthop 115: 396-400.

21. Tongkobpetch S, Siriwan P, Shotelersuk V (2006) MSX1 mutations contribute to nonsyndromic cleft lip in a Thai population. J Hum Genet 51: 671-676.

22. Zhang Z, Song Y, Zhao X, Zhang X, Fermin C, et al. (2002) Rescue of cleft palate in Msx1-deficient mice by transgenic Bmp4 reveals a network of BMP and Shh signaling in the regulation of mammalian palatogenesis. Development 129: $4135-4146$.

23. Hilliard SA, Yu L, Gu S, Zhang Z, Chen YP (2005) Regional regulation of palata growth and patterning along the anterior-posterior axis in mice. J Anat 207 $655-667$.

24. Peters H, Neubuser A, Kratochwil K, Balling R (1998) Pax9-deficient mice lack pharyngeal pouch derivatives and teeth and exhibit craniofacial and limb abnormalities. Genes Dev 12: 2735-2747.

25. Blin-Wakkach C, Lezot F, Ghoul-Mazgar S, Hotton D, Monteiro S, et al. (2001) Endogenous Msx1 antisense transcript: In vivo and in vitro evidences, structure, and potential involvement in skeleton development in mammals. Proc Natl Acad Sci USA 98: 7336-7341. 